\title{
"Planned" permanent pacemaker implantation in one-day-old newborn after prenatal diagnosis of congenital complete atrioventricular heart block
}

\author{
Ireneusz Haponiuk ${ }^{1,2}$, Maciej Chojnicki ${ }^{1}$, Aneta Szofer-Sendrowska ${ }^{1}$, Jacek Juscinski ${ }^{1}$, Mariusz Steffens ${ }^{1}$, \\ Radoslaw Jaworski ${ }^{1}$, Iwona Domzalska-Popadiuk ${ }^{3}$, Katarzyna Gierat-Haponiuk ${ }^{4}$, Katarzyna Leszczynska ${ }^{5}$, \\ Krzysztof Preis 5
}

\author{
${ }^{1}$ Department of Pediatric Cardiac Surgery, Mikołaj Kopernik Hospital in Gdansk, Poland \\ ${ }^{2}$ Chair of Physiotherapy, Gdansk University of Physical Education and Sport, Poland \\ ${ }^{3}$ Department of Neonatal Intensive Care, Medical University of Gdansk, Poland \\ ${ }^{4}$ Department of Rehabilitation, Medical University of Gdansk, Poland \\ ${ }^{5}$ Department of Gynecology, Medical University of Gdansk, Poland
}

Kardiochirurgia i Torakochirurgia Polska 2014; 11 (1): 76-78

\begin{abstract}
We present a case of a severely ill newborn with congenital atrioventricular heart block (CAVB) diagnosed prenatally. The initial drug therapy just after birth was ineffective, the heart rhythm remained 54 beats per minute, and control echocardiographies showed forthcoming decrease of the left ventricular function with mitral insufficiency. A permanent pacing system with bipolar electrodes eluting two steroids (Medtronic Capsule, Medtronic Inc. Minneapolis, USA) and Medtronic ADAPTA $^{\circledR}$ pulse generator (Medtronic Inc, Minneapolis, USA) was implanted on the first day of life. The pace control as well as wound healing were uncomplicated, and the baby was discharged home without additional medication. The procedure of permanent pacemaker implantation on the first day of life was safe and effective, as a benefit from a successfully performed prenatal program in our cooperating institutions.

Key words: congenital complete atrioventricular block, permanent stimulation, pacemaker, pediatric cardiac surgery, neonatology, newborns.
\end{abstract}

\section{Streszczenie}

W pracy przedstawiono opis przypadku leczenia noworodka w stanie krytycznym z wrodzonym blokiem przedsionkowo-komorowym, rozpoznanym w badaniach prenatalnych. Wdrożona terapia farmakologiczna okazała się nieskuteczna, rytm serca po urodzeniu pozostał na poziomie 54/min, w ocenie echokardiograficznej funkcja lewej komory serca pogorszyła się z postępującą niedomykalnością zastawki mitralnej. Na podstawie bieżącej oceny stanu klinicznego podjęto decyzję o wszczepieniu stałego nasierdziowego układu stymulującego z bipolarnymi elektrodami sterydowymi (Medtronic Capsule, Medtronic Inc. Minneapolis, USA) i generatorem Medtronic ADAPTA (Medtronic Inc., Minneapolis, USA) w pierwszej dobie życia dziecka. Kontrola stymulacji i gojenie ran było prawidłowe, dziecko zostało planowo wypisane do domu bez potrzeby stosowania dodatkowych leków. Zabieg wszczepienia stałego stymulatora nasierdziowego u noworodka w pierwszej dobie życia okazał się skuteczny i bezpieczny, dzięki skutecznemu programowi badań prenatalnych i wielospecjalistycznej współpracy kilku ośrodków.

Stowa kluczowe: wrodzony całkowity blok przedsionkowo-komorowy, stała stymulacja serca, stymulator, kardiochirurgia dziecięca, neonatologia, noworodki.

presentation of prenatally diagnosed isolated CAVB, although usually found incidentally, is associated with generally poor prognosis and the rate of $19 \%$ to $31 \%$ mortality [1] Fetal medical therapy with betamethasone remains controversial and is administered optionally. The diagnosis of refractory CAVB is rarely reported as the indication for pacing in the first 24 hours after birth, usually in patients

Address for correspondence: Ireneusz Haponiuk, Department of Pediatric Cardiac Surgery, Mikolaj Kopernik Pomeranian Centre of Traumatology, 1-6 Nowe Ogrody Str., 80-803 Gdansk, Poland, phone/fax.: +48 5876408 27, e-mail: ireneusz_haponiuk@poczta.onet.pl 


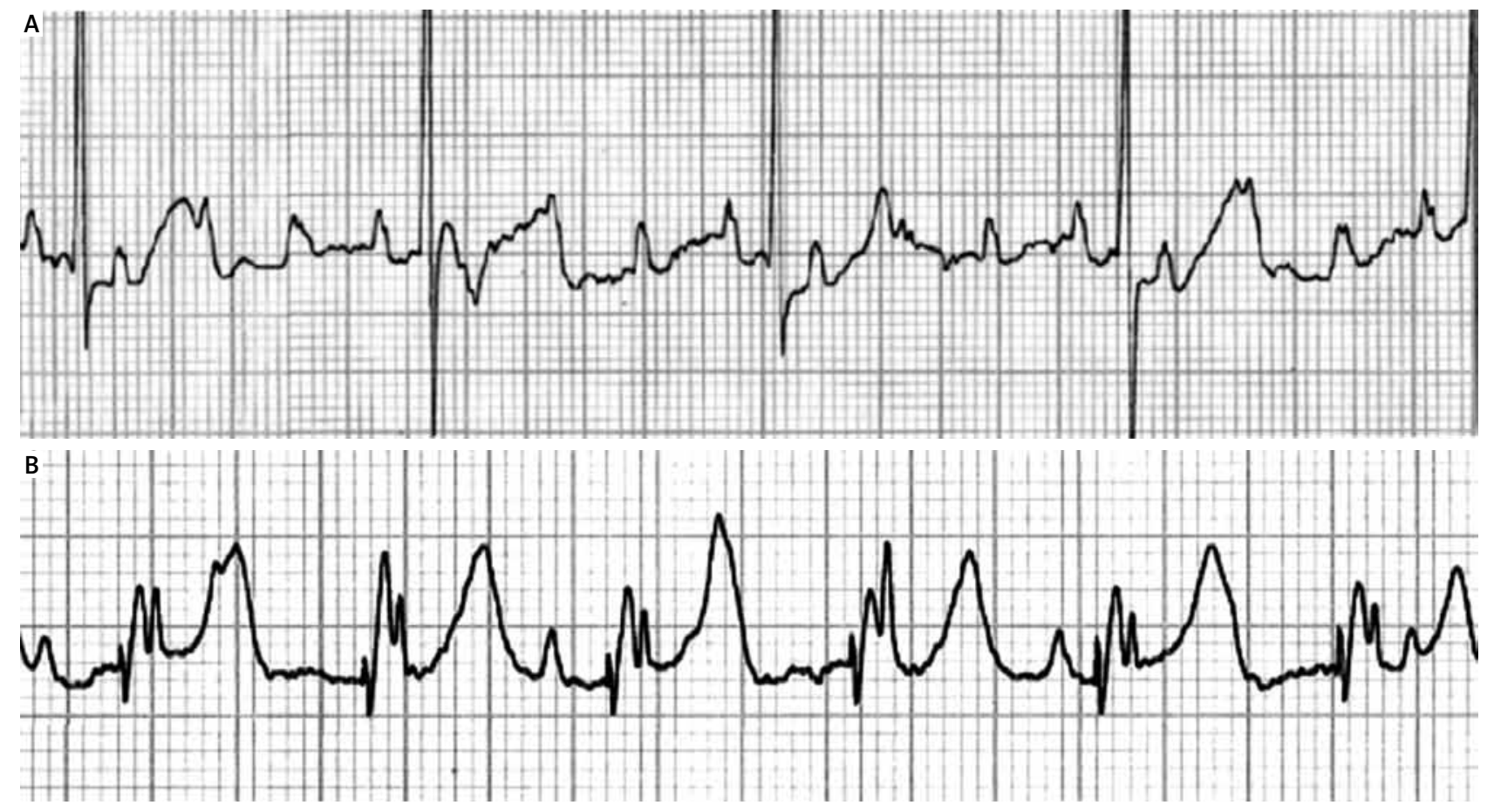

Fig. 1. Preoperative and postoperative electrocardiograms (paper speed $25 \mathrm{~mm} / \mathrm{s}$ ): note the initial complete AV block - HR 54/min (A), and effective epicardial pacing postoperatively - HR 120/min (B)

with compromised cardiac output and circulatory collapse, in a staged strategy [1]. Despite the advancement of contemporary pacing therapies pacemaker implantation in small babies remains a challenge, although the technological progress in generators, leads and programmability enables permanent stimulation in newborns, with spectacular reports of premature low body weight patients treated with artificial stimulation [2].

We present a case of a one-day old newborn with fetal diagnosis of CAVB at the $17^{\text {th }}$ week of gestation, who underwent successful "planned" permanent pacemaker implantation immediately after birth.

\section{Case report}

A term birth newborn boy (body weight $3 \mathrm{~kg}$ ), delivered by cesarean section in the $38^{\text {th }}$ gestational week from a collagenosis negative mother, was admitted to the Department of Pediatric Cardiac Surgery, Pomeranian Centre of Traumatology in Gdansk (Poland), with the diagnosis of congenital complete atrioventricular block (CAVB) observed from the $17^{\text {th }}$ week of gestation. The initial drug therapy with intravenous isoproterenol and dobutamine appeared ineffective, the heart rhythm remained 54 beats per minute (Fig. 1), while control echocardiographies performed every four hours showed the decrease of the left ventricular function with the increase of mitral insufficiency. With regard to fetal diagnosis and the symptoms of critical heart block, the newborn was qualified for immediate permanent pacemaker implantation.

After the parents of the described child had given their informed consent for implantation of the pacemaker, the baby was prepared for the procedure in a routine fashion, with vascular access lines and tracheal intubation typical for cardiovascular procedures. The double approach with transxiphoid lower ministernotomy and additional abdominal wall cuff was chosen because of limited space

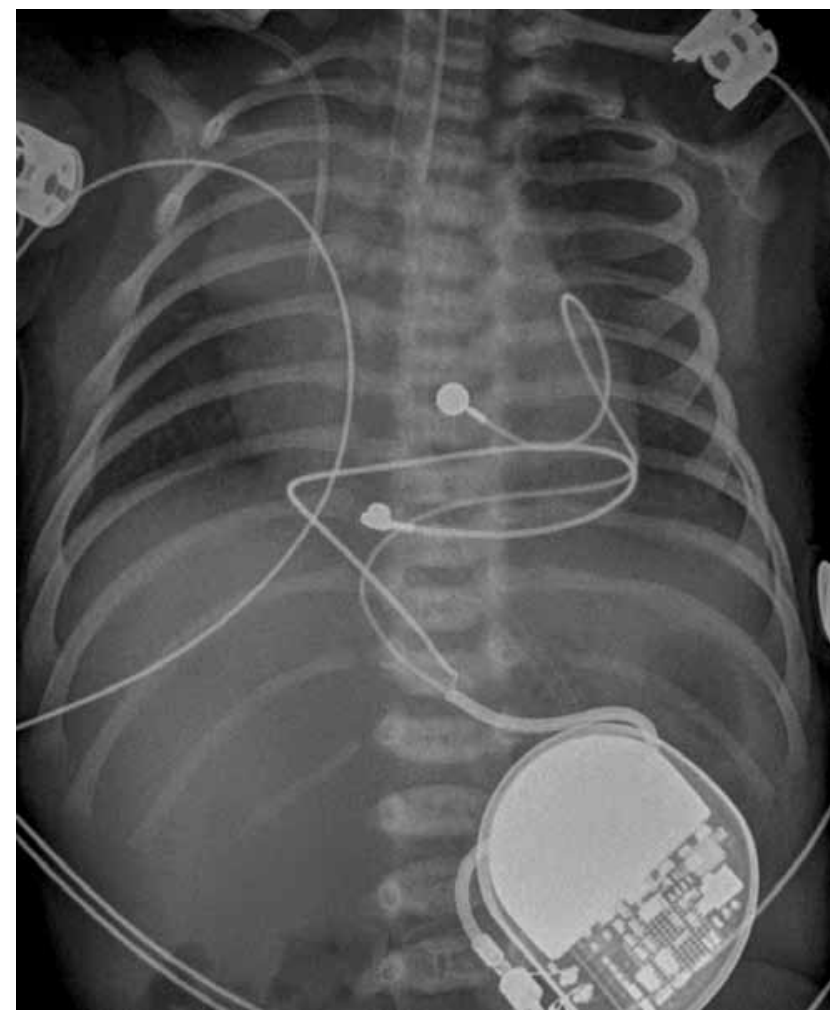

Fig. 2. Postoperative chest X-ray - the electrodes on the right ventricle and the Medtronic generator implanted in the left sided upper abdominal wall are seen 
in a small patient, preventing the procedure of epicardial lead application and generator implantation via a single incision. After a limited midline pericardiotomy the anterior and inferior walls of the heart were exposed. A bipolar catheter with an electrode eluting two steroids (Medtronic Capsule, Medtronic Inc. Minneapolis, USA) was implanted on the anterior and inferior surface of the right ventricle. The leads were fixed to the epicardium surface with prolene suture. The $Y$ wire of $25 \mathrm{~cm}$ was passed through and placed into the left-sided abdominal pocket, where the Medtronic (ADAPTA ${ }^{\circledR}$ ADSR01, Medtronic Inc, Minneapolis, USA) pulse generator was implanted. A small incision between the left rectus abdominal muscle and the posterior sheath was performed, to create the cavity for the generator and the wire (Fig. 2). The pacemaker was self-captured just after initial management of the impedance and control of the pacing. The initial rate of the generator was set for 120 beats per minute, with the output 0.5 volts in VVI stimulation.

The baby was extubated two hours after the procedure, and referred for final treatment in the cardiology department. The boy was discharged home on the sixth postoperative day. The wound healing and the stimulation were uncomplicated during the six months of postoperative follow-up.

\section{Discussion}

The final good result of treatment of the presented newborn with critical CAVB was related to very precise and effective prenatal diagnostics, as well as close cooperation between referral gynecology, neonatology and cardiac centers. The prenatal program makes it possible to screen the population for congenital heart defects and arrhythmias, with prenatal introduction of circulatory drugs, and in-utero interventions when indicated. The true value derived is a modern strategy to treat prenatally diagnosed heart defects in a so-called "planned" fashion, with teams of specialists, technical support and pre-trained skills to perform the most complicated diagnostics and interventional procedures in newborn cardiac patients [3]. Nevertheless, the risk factors associated with a poor outcome in isolated atrioventricular block in the fetus are gestation < 20 weeks, ventricular rate $\leq 50 \mathrm{bpm}$, hydrops, and impaired left ventricular function [4]. In our patient the pacing system itself and the whole procedure were planned from the very beginning of the labor, and thus the baby was treated with definitive single-stage permanent stimulation, without the need for temporary epicardial external pacing typical for cardiac procedures [5].

There is no doubt that permanent pacing in the pediatric population is a well-established and effective strategy $[1,6]$. Nevertheless, there still appear additional technical problems, with the most important being the oversize of the generators and leads, especially when there is a need to implant the set in a very small heart [5]. The transxiphoid approach with abdominal cuff is our routine technique in small babies, although other lateral incisions could be effectively considered in such a situation $[2,6]$. It would be an ideal option to implant the ventricular electrode on the left, rather than right ventricle. This would provide some sort of resynchronization, and may protect from pacing-induced heart failure. In our opinion, however, the risk related to gaining access to the left ventricle in a newborn would be too high, especially as a life-saving strategy. Ventricularonly stimulation in a patient with sinus rhythm is far from physiologic in the longer run; therefore, upgrade to a dualchamber device seems to be unavoidable in our patient. We believe that the generator exchange in the future will appear possible without the need for troublesome resternotomy, because of its abdominal location and the spare length of the wires collected in place. We usually make maximal efforts to avoid any predictable complications, the most important being peritoneal opening, bleeding, mediastinal infections and local hernias. The surgical trauma appeared acceptable, and the patient was successfully extubated immediately, with regular antibiotics and laboratory tests after surgery.

The follow-up was uneventful. The baby underwent regular outpatient controls. The pacemaker parameters were controlled, no pacing disturbances were noted, and no dislocation of the generator was reported.

\section{Conclusions}

The procedure of "planned" permanent pacemaker implantation on the first day of life was safe and effective, without any concomitant complications. The benefits from "planned" emergency interventions come from precise cooperation with the specialist who successfully performs the prenatal program in our institutions.

\section{References}

1. Glatz AC, Gaynor JW, Rhodes LA, Rychik J, Tanel RE, Vetter VL, Kaltman JR, Nicolson SC, Montenegro L, Shah MJ. Outcome of high-risk neonates with congenital complete heart block paced in the first 24 hours after birth. Thorac Cardiovasc Surg J 2008; 136: 767-773.

2. Di Coste A, Cassano V, Troise D, Annecchino FP. Pacemaker implantation in a premature low weight newborn with critical congenital atrioventricular block. G Chir 2011; 32: 307-309.

3. Haponiuk I, Chojnicki M, Jaworski R, Sroka M, Steffek M, Czauderna P. Congenital pericardial defect with Gerbode type septal defect in rotated heart - report of a case and literature review. Kardiochirurgia Torakochir Pol 2010; 7: 276-279.

4. Eliasson H, Sonesson SE, Sharland G, Granath F, Simpson JM, Carvalho JS, Jicinska H, Tomek V, Dangel J, Zielinsky P, Respondek-Liberska M, Freund MW, Mellander M, Bartrons J, Gardiner HM; Fetal Working Group of the European Association of Pediatric Cardiology. Isolated atrioventricular block in the fetus: a retrospective, multinational, multicenter study of 175 patients. Circulation 2011; 124: 1919-1926.

5. Welch EM, Hannan RL, DeCampli WM, Rossi AF, Fishberger SB, Zabinsky JA, Burke RP. Urgent permanent pacemaker implantation in critically ill preterm infants. Ann Thorac Surg 2010; 90: 274-276.

6. Agarwal R, Krishan GS, Abraham S, Bhatt K, Sekar P, Kulkarni S, Cherian KM. Extrapleural intrathoracic implantation of permanent pacemaker in pediatric age group. Ann Thorac Surg 2007; 83: 1549-1552. 